\title{
The Stories of English Teachers as Learners in Terms of Teacher Socialization ${ }^{1}$
}

\author{
Esra Harmandaoğlu $\mathrm{Baz}^{2}$
}

\begin{abstract}
This study aims to find out whether there is a relationship between the stories of teachers as learners in their socialization process and what kind of differences emerge between novice and experienced teachers in terms of their referring to that process from their perspective. The study was designed qualitatively and data were gathered by semi-structured interviews in order to reveal teachers' stories as learners from their perspectives. Expert judgment was taken and pilot study was conducted before the actual study in order to make sure that the research questions are clear and understandable. Four English teachers from Turkey took part in the study in 2014-2015 spring term. The data were analyzed using content analysis and coding in order to form the recurring patterns from teachers' expressions about teacher stories as learners from the teachers' perspective and find the differences between experienced and novice teachers in terms of referring to teachers' socialization process. The findings indicate that while novice teachers in this study tend to focus on the problems they face and their reflection from their previous stories as learners, experienced teachers tend to talk about their experiences in a paternalistic manner by featuring their personality and self-confidence. The results highlight the prominence that must be given to the stories of teachers as learners and the need for in-depth analysis.
\end{abstract}

Keywords: English teacher socialization, narrative inquiry, the stories of teachers as learners

\footnotetext{
${ }^{1}$ The study was presented as a paper presentation at the "PAEDEIA Conference: European Symposium Young Teachers as Change Agents", which was held in Ankara (Turkey) on October 21-23, 2015.

${ }^{2}$ Res.Assist. Gazi University, Faculty of Education, English Language Teaching Department, esraharmandaoglu@gmail.com
} 


\section{İngilizce öğretmenlerinin Öğretmen Sosyalleşmesi Açısından Öğrenciliklerine İlişkin Hikayeleri}

\section{$\ddot{\mathbf{O z}}$}

$\mathrm{Bu}$ çalışmada, öğretmenlerin kendi perspektiflerinden öğrenciliklerine ilişkin hikâyeleri ile öğretmen sosyalleşmesi arasında bir ilişki olup olmadığını ve bu süreci anlatırken deneyimli ve yeni öğretmenler arasında ne tür farklılıklar oluştuğu araştırılmıştır. Nitel yöntem ile kurgulanan çalışmada veriler öğretmenlerin kendi perspektiflerinden öğrenciliklerine ilişkin hikâyelerini açığa çıkarmak için yarı yapılandırılmış görüşme formu aracılığıyla toplanmıştır. Çalışmadan önce soruların açık ve anlaşılır olduğundan emin olmak için uzman görüşü alınıp pilot çalışma yapılmıştır. Çalışmada Türkiye'den 2014-2015 bahar döneminde dört tane İngilizce öğretmeni yer almıştır. Veriler öğretmenlerin kendi perspektiflerinden öğrenciliklerine ilişkin hikâyelerinde tekrar eden öğeleri bulmak ve öğretmen sosyalleşmesi sürecinden bahsederken deneyimli ve yeni öğretmenler arasındaki farklılıkları belirlemek için içerik analizi ve kodlama yoluyla analiz edilmiştir. Çalışmanın sonucunda yeni öğretmenlerin kendi hikâyelerinden yansımalara ve karşılaştıkları problemlere odaklanırken deneyimli öğretmenlerin kişilik ve öz güvenlerini ön plana çıkararak babacan bir tavırla deneyimlerinden bahsettikleri yönünde bir eğilime sahip oldukları gözlenmiştir. Bulgular öğretmenlerin öğrenciliklerine ilişkin hikâyelerine ve derinlemesine analiz ihtiyacına önem verilmesi gerektiğini vurgulamaktadır.

Anahtar kelimeler: İngilizce öğretmeni sosyalleşmesi, öyküleme, öğretmenlerin ögrenciliklerine ilişkin hikayeleri 


\section{Introduction}

It has been mostly accepted that learning how to teach is not a simple process (Bruckerhoff \& Carlson, 1995; Featherstone, 1993; Solmon, Worthy, \& Carter, 1993) and the first years are really important for the long years waiting for the novices (Solmon et al., 1993). No one can deny that jumping from teacher education programs to real classroom environment is a kind of reality shock (Veenman, 1984); and this kind of adaptation process and trying to become a member of the school culture are called teacher socialization. As Calderhead (1992, p. 6) emphasizes, "the novice becomes socialized into a professional culture with certain goals, shared values, and standards of conduct". Teacher socialization is a multifaceted, dynamic, complex, and situated process through which a teacher candidate turns into a participating member of the society of teachers (Zeichner \& Gore, 1990). In this respect, there are three main traditions in teacher socialization field, namely, functionalist, interpretive, and critical (Zeichner \& Gore, 1990). Functionalist approach sees the public superior to individual and gives a tremendous effort to maintain the social norms, inherit values, and provide consensus (Burrell \& Morgan, 1979). It can be said that this approach supports "realist, determinist, positivist, and nomothetic" views towards socialization (Burrell \& Morgan, 1979, p. 26).

Contrary to functionalist approach, interpretive approach gives importance to the individual's own subjective and unique experience in the society (Burrell \& Morgan, 1979). The views that interpretive approach is in favor of are "nominalist, antipositivist, voluntarist, and ideographic" (Burrell \& Morgan, 1979, p. 28). Although both approaches have a different ontological understanding of the society, both have in common in terms of "sociology of regulation, a concern to provide explanations of society in terms which emphasize its underlying unity and cohesiveness" (Burrell \& Morgan, 1979, p. 17).

What is emphasized in critical approach is that the individuals are both observers and the participants of the society. Due to this, the aim of the critical approach is raising awareness for the skill to criticize what is accepted in the society without questioning (Zeichner \& Gore, 1990). The ultimate aim can be assumed as "increasing justice, equality, freedom, and human dignity" (Zeichner \& Gore, 1990, p. 5). We can understand that "class, gender, and race relations" are the focus points in particular groups and significant critical research should be conducted on these concepts. According to Zeichner and Gore (1990), the functionalist 
approach is in favor of explanation, the interpretive approach supports interpretation, and the critical approach is about transformation.

Teacher socialization is generally viewed in three main phases: influences on teacher socialization prior to formal teacher education, the socialization role of pre-service teacher education, and socialization in the workplace and culture. In theoretical framework section, these phases and their impact to teacher socialization process were explained.

\section{Theoretical Framework}

\section{Influences of prior to formal teacher education on teacher socialization}

It has been understood that students have their experiences, past habits and learned behaviors and they unavoidably bring these to any learning environment and these have an effect on teacher socialization (Bliss \& Reck, 1991; Duff \& Uchida, 1997; Farrell, 1999; Uzum, 2013; Zeichner \& Gore, 1990). Lortie (1975) suggests that these kinds of predispositions have a much more important effect on the socialization process of teachers during the pre-service program and in the work place.

Based on these, Feiman-Nemser (1983) suggests three models for predispositions: an evolutionary model, psychoanalytical model, and apprenticeship of observation. In the first place, Stephens (1967) comes up with the concept of 'evolutionary theory' in teacher. According to Feiman-Nemser (1983), humans naturally tend to observe the other, correct their mistakes, share what they know and help each other. These tendencies pass from generation to generation and appear in the family and school environment. Due to this, the children both have the knowledge of what is shared by their families and learn to be teachers. 'The psychoanalytical model' has its roots in the studies of Wright (1959) and Wright and Tuska (1967). This model explains that the teachers had some crucial adults like mother, father or teachers when they were children and this interaction process has a tremendous effect on teacher socialization because whether consciously or unconsciously, the teachers have the potential of imitating these important figures in their life (Zeichner \& Gore, 1990). 
The last model we will mention is 'the apprenticeship of observation'. According to Lortie (1975), the teachers do lots of observations during their time as students about their teachers. These observations can have effects on teachers and these effects can be both positive and negative but it must be underlined that every teacher reflects upon these experiences and shapes their identity as a teacher in terms of these factors (Zeichner \& Gore, 1990).

Based on the theories above, it must be underlined that it must be given enough importance to learn the life stories of teachers and more qualitative research should be carried out in this area because it can be said that these pre-training processes have a relationship with teacher socialization.

\section{The socialization role of pre-service teacher education}

According to Zeichner and Gore (1990), there are three main areas in pre-service teacher education programs: a) general education and academic specialization courses completed outside schools, departments, and colleges of education, b) methods and foundations courses usually completed within education units, and c) field-based experiences usually carried out in elementary and secondary school classrooms.

What is interesting is that there is little research into the effect of the type, quality, intellectual, social, and political character of the institutions of teacher education programs and whether they affect teacher socialization (Zeichner \& Gore, 1990). In addition, Ginsburg and Clift (1990) mention the effect of hidden curriculum and suggest that this may also have some effect on teacher socialization actually establishing "the core".

The last aspect of pre-service education is about the practicum. Research indicates that there can be a mismatch between theory and practice in teacher education programs (Akcan, 2016; Darling-Hammond \& Bransford 2005; Hammerness, 2006; Korthagen et al., 2001; Ure, 2010). Therefore, it can be assumed that the novice teachers can have trouble in their socialization process due to this mismatch. 


\section{Socialization in the workplace and culture}

According to Pollard (1982), there are three layers of social contextualization, namely, cultural, institutional, and interactive factors. The role of the pupils and the classroom environment are crucial in teacher socialization in terms of 'interactive factors'. The role of the pupils has been considered crucial and it has been observed in the study of Haller (1967) that elementary teachers tend to use a simplified speech and this shows a strong effect of pupils on teacher socialization (Doyle, 1979; Haller, 1967).

Pollard (1982) considers the schools under the category of 'institutional factors'. Zeichner and Gore (1990) divides the school effect in terms of socialization into two: the influence of teaching colleagues and the influence of evaluators. It can be suggested that in-depth analysis is necessary in order to understand the relationship more clearly.

The last factor in Pollard's (1982) layer is the 'cultural factor' on teacher socialization. According to Arfwedson (1979), it is hardly possible to find a common working condition for all teachers because every working condition differs from school to school and this difference is highly affected by the social environment around the school. In terms of this, children must be taken into account in terms of their families, their socioeconomic conditions, their social class, and interests and it cannot be denied that there is a parental pressure from the parents, which can be a triggering factor for teacher socialization whether teachers obey these pressures consciously or not in order to adapt to their work (Zeichner \& Gore, 1990).

In Crow's study (1987), it is emphasized that the contributions of the teachers' own personal perspectives are a lacking part in teacher socialization concept, which is the underlying point of this study. This detection may give some emphasis to the interpretive approach as suggested in the literature above. What is more, it is emphasized in this study that this kind of research was required due to the fact that the novices were perceived as passive elements in socialization process in the beginning, they should be given more chances to express themselves to the institutions. A grounded theory research approach associated with ethnographic studies (formal/informal interviews, shadowing of informants throughout their formal teacher preparation program, review of program documents and observation) was used in the study in order to understand the relationships and interrelationships. In the results, it 
was revealed that the individuals took part in the interpretation and construction of events and they were active during their teacher education program. Farrell's study (2001) draws our attention to the fact that there actually occurs a gap between pre-service and in-service training. This study is also crucial in terms of being one of the few studies in language teacher socialization process. The researcher worked with one trainee teacher, who is enrolled for Post Graduate Diploma in Education (PGDE), and he was the supervisor of the trainee teacher. Farrell (2001) looked into the reflections of this teacher trainee about his. Practicum. Using a qualitative case study, Farrell conducted a nine-week-practicum data collection process. Data were gathered via electronic mail discussions, telephone calls, classroom observations, and two-in-depth interviews one before and the other immediately after the practicum. The results showed that the trainee teacher had some difficulty in support and communicating with his cooperating teacher and institution. What he felt is lack of desire for teaching in that school after the practicum. So, it can be assumed that it seems highly important to provide a transition between those fields mentioned by Zeichner and Gore (1990) in pre-service education. Also, it was understood from the comments of the trainee teacher that in the beginning he focused on his 'self' rather that the students, which is a natural and very crucial socialization progress (Kagan, 1992). So, what is needed is more collaboration between the supervisor, cooperating teacher, and trainee teacher. Uzum (2013) has conducted a study looking at the transitions between institutions (from pre-service to in-service) and between cultures (from Turkish or Uzbek context to American context). The out point of this study is related to socialization prior to formal education and supports the idea that teachers bring to the classroom their habits, observations as learners and these have crucial effect on their socialization process. In this study, ethnographic multiple case study design was used. The results were parallel to the notions of that the natural characteristics of human beings, teachers' experience as learners, their interaction with the pupils and institutions and their subject matter knowledge have an effect on their socialization process.

From Turkey context, Akbulut (2007) searched novice English teachers' concerns and whether they could implement what they acquired in their teacher education program into real classrooms. The participants claimed to be communicative in their teaching. On the other hand, they somehow were surpassed possibly owing to "the constraints of the educational institution or course overload of the teachers" (Akbulut, 2007, p. 10). Additionally, Aydin (2012) investigated the factors inducing teacher demotivation in EFL teaching contexts at the 
elementary education level. The findings indicate that the problems are about "teaching profession, curriculum, working conditions, students and their parents, colleagues and school administrators, and physical conditions" (Aydin, 2012, p. 1). Akcan (2016) looked for fiftyfive novice non-native English teachers' comments about the efficiency of their teacher education programs and the problems they encountered in their initial years of teaching career. Using survey and follow-up interviews in her study, Akcan (2016) came up with such issues as "more emphasis on theory rather than practice, implementation of the communicative approach in classrooms, classroom management, unmotivated students, and students with learning disabilities" (pp. 61-62).

It can be said that teacher socialization is a long and complicated process. There seem to be many factors affecting this process starting from the earlier childhood to teacher education programs. Hence, knowing about the stories of teachers as learners can hold an important place in explaining this complicated process. Also, Staton and Hunt (1992, p. 113) propose that "teacher socialization experiences are distinctive not only because of the effects of the biography, but because unique individuals interact within unique environments". Therefore, it seems necessary to have knowledge about their experiences as learners and to the knowledge of the researcher, there is no study investigating the teacher stories as learners in relation to teacher socialization process and the differences between experienced and novice teachers in terms of referring to their stories as learners. In this respect, the research questions of this study are as below:

1. How do teachers mention their socialization process?

2. What kinds of differences occur between novice and experienced teachers in terms of stories related to their socialization process?

\section{Research Methodology}

This study was designed as an interpretive approach. Recent trend shows that it seems crucial to have knowledge of the teacher's stories in order to have a deeper understanding of the phenomenon, as stated by Barkhuizen, Benson and Chik (2014) "the main strength of narrative inquiry lies in its focus on how people use stories to make sense of their experiences in areas of inquiry where it is important to understand phenomena from the perspectives of those who experience them" (p. 2). Furthermore, the reflective practice (Schön, 1983) and 
teacher research have strengthened the focus on listening to the voice of teachers and hearing their stories. Therefore, narrative inquiry was used and as $\mathrm{Xu}$ and Connelly (2009, p. 221) state "philosophically, narrative inquiry is less about method than it is about the phenomena studied via method. For this reason we define narrative inquiry as both phenomenon and method.". Therefore, narrative inquiry is both a method and a phenomenon.

\section{Participants}

Four English teachers from Turkey were involved in the study in 2014-2105 spring term. As can be observed in table 1, two of them were experienced English teachers and the other two were novice English teachers. Their original names were changed by pseudonyms. They were chosen by purposive sampling owing to the fact that "in almost all qualitative research, the sample is a purposive sample. Random sampling ordinarily is not feasible, since the researcher wants to ensure that he or she obtains a sample that is uniquely suited to the intent of the study" (Fraenkel, Wallen, \& Hyun, 2011, p. 430).

Table 1

The Profile of the Participants

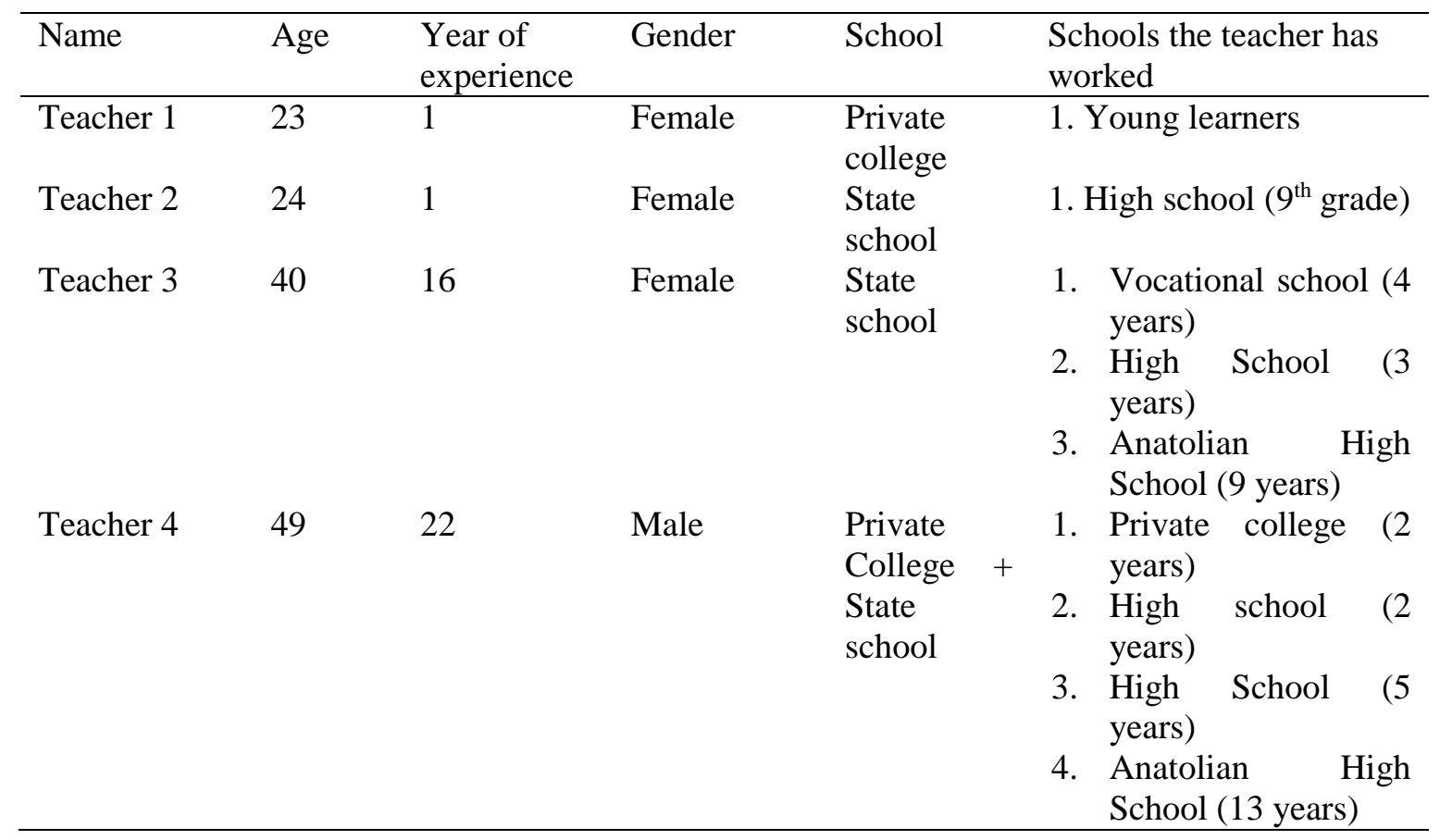




\section{Data Collection and Analysis}

Data were collected via semi-structured interviews in order to reveal teachers' stories as learners from their perspective. The interview questions were prepared under three categories:

- Influences on teacher socialization prior to formal teacher education

- Socialization role of pre-service teacher education

- Socialization in the workplace and culture

Expert judgment from an associate professor interested in teacher education field was taken for the subfields and appropriacy of the questions in relation to teacher socialization. A pilot study was conducted in order to make sure that the questions are clear and understandable to the participants. The interview was conducted in the native language of the participants in order to obtain more in-depth data. The interviews were audio-recorded with the permission of the participants and audio-records were transcribed verbatim. Afterwards, related parts were translated by the researcher. Content analysis was applied in order to form the recurring patterns from their stories as learners from their perspective and find the differences between experienced and novice teachers in terms of referring to teachers' socialization process. "Content analysis is the intellectual process of categorizing qualitative textual data into clusters of similar entities, or conceptual categories, to identify consistent patterns and relationships between variables or themes" (Given, 2008, p. 120). In this study, coding process was used for "keeping notes on insights, ideas, patterns, and connections that occur to us as we read and reread the data" and this kind of coding is called 'memoing' (Given, 2008, pp. 85-86). Whatever the purpose is for coding, the aims are "to identify categories and themes by making their criteria explicit and providing evidence for them-and the conclusions based on them - that is drawn from the data" (Given, 2008. p. 86).

\section{Findings and Discussion}

The short stories of the participants related to English learning process are presented below in order to provide a general perspective related to teachers' English learning process. 


\section{Teachers' reflections: Their own English learning process}

\section{Teacher 2}

Teacher 2 started to learn English at the 4th grade with a teacher whose main focus was based on memorization. "My secondary school teacher was like a leader to us and led us to make more sentences and produce something". She had preparatory class at the high school and had main course lessons, studying all the skills one by one. However, after the preparatory, there was no emphasis on the listening and speaking skills but on tests. She also did some extra activities on her own like translating the song lyrics and poems, checking the translation of the lyrics in free time, trying to do listening, watching TV series with subtitles on TV when available.

\section{Teacher 3}

Teacher 3 graduated from the college and she liked English very much. Her teacher was very sincere and serious towards them. She remembers "we never spoke Turkish and when we did, we used to give money". She also did not need to do anything extra but she clarifies that she did her homework properly. The books directly coming from the England enchanted her. She did lots of activities related to listening, reading, speaking and writing. The focus in the first place was not on grammar and she learned the headings of the grammar topics at the university.

\section{Teacher 4}

Teacher 4 graduated from college and she had a native English teacher, Mary, there. "She was the one who made me like English. She was married to a Turkish guy and due to the fact that she did not know Turkish, we had to learn something in order to communicate with her". Teacher 4 did not do anything extra to practice English. "English is appreciated very much at colleges. They taught us English very well. We used to watch movies in English at our lab. My pronunciation got better. Then, I got to English Language Department at the university. The college had direct effect on my choosing this department". 


\section{Teacher 1}

Teacher 1 started to learn English at the 4th grade at the age of 10. A religion teacher was giving the course. At the 7th and 8th grade, she had an English teacher she liked very much and she tells "English got my attention, which happened via my secondary school teacher". She still remembers joyfully how he played English games with them. Then, she chose foreign language department at the high school. She developed her grammar at the high school (mostly due to the examination system) very much however there was lack of speaking and writing. She had some extra study to develop especially her listening skills by listening to music, watching foreign TV series, and doing some translation of the songs. She believes that she studied hard at the high school. Then, she had access to English Language Department at the university, which she believes that she developed her speaking skills in order to be able to communicate in English in the lessons.

\section{Codes regarding teacher stories as learners in terms of teacher socialization}

In the following part, results of the analyses and discussion of the findings are presented. As a result of the content analysis, the codes were extracted. Each teacher's own expression related to each code was provided in the italics. Firstly, the first research question of the study was discussed.

1. How do teachers mention their socialization process?

\section{Predispositions}

Teacher 4 clearly explains that the reason he chose to be an English teacher was Mary. "I take Mary as an example. She is the reason of my interest in English. I learnt the things I should do from Mary and I learnt the things I should not do from those like geography or history teacher. That is why I became an English teacher". Teacher 4 got very impressed by the style of Mary. "She was my idol. We all liked her. She was not like our geography or history teacher, she was very different because she was not like a classic teacher. She was approaching us very well and very different. What I learnt from her is that if you want to teach a student English, you have to make sure that they like you. If the student does not like 
you or admire you, you cannot do this job. Due to this, I try to endear myself in the first place. How? I make jokes in the class and the students get relaxed in my lesson".

Teacher 4 adds that omitting the private college he worked in the beginning, he admits that he felt like an English teacher in the third place he worked. "I always wanted to have a foreign language class. This unconscious mind about this was affected by Mary. I always have foreign language classes because they are like your regular class with 24-hour of English per week. I had job satisfaction there. For example, speaking in Turkish was forbidden and if anyone does, that student has to give money. These are all reflections from Mary".

Teacher 3 had her practicum at the university and very satisfied with her mentor teacher at the university. Furthermore, she remembers good impression from her practicum teacher visually. "There is no option for an English teacher to be passive. She used to dress up in a pretty way and I also believe that it is important to address the students visually". Teacher 3 tells the practicum teacher used to do speaking, listening, and writing activities from the book, and she did not bring extra material to the class due to course book load. Teacher 3 remembers her teacher kind but firm. She does not remember very much about her demo lessons, "I do not remember we practiced so much rather we did observation, but it was the stuff we learnt at the university". Teacher 3 adds that she used to prepare materials on her own and the teacher was just giving the parts.

Teacher 2 says that she does not encourage group work due to the fact that she does not like it from her own experiences as a learner. This supports the idea that teachers shape the classroom environment from their own experiences as a learner and they teach the way they were taught (Lortie, 1975). Besides, Teacher 2's father is a French teacher and Teacher 2's mother is a German teacher. "We always talk about the lessons. My father says he did textual analysis and the students liked it. He advises me to do it and I go to the class and do it, too. They also help me about methodology and administrative work". Teacher 2 also remembers their parents' teaching styles because at one time, she was their student. "I also remember my father's actions in the class. For example, I am humorous as he is in the class. However, I sometimes turn into a serious person out of nowhere as he does". Teacher 2 also clarifies that her secondary school and high school teacher had some impacts on her development as a 
teacher. "My secondary school teacher with a humorous manner had a lot of impact. Besides, I tear that 'cold teacher image' in the class".

Teacher 1 admits that she has always listened to her mother's advices and she also listened to her suggestion when she started the profession. "My mother always advised me to observe the people and the situation in the first place. If you step forward, you will make yourself understood clearly. The things can work out bad for you. Due to this, firstly, I was quiet at the school. I was equally distant to everyone". Teacher 1 also adds that if she had not listened to her mother and it were up to her how to behave at school, she would have freaked out due to lack of plans and had been in trouble. Also, Teacher 1 applies some activities working in her practicum class in her own class now. "I saw that warm-up working in the practicum class and I got the attention of the students. I saw it was working so I apply them now due to the fact that it worked in my practicum". Teacher 1 also affected from her teacher at the university. "One of our teachers at the university used to have us make one sentence about what we have learnt in that lesson before we left the class. I do this also in my classes. I also give them homework about what they have learnt". "In the $2^{\text {nd }}$ grades, I take my young learners teacher at the university as an example. When I have a lesson to young learners, I dress casually. I wear comfortable shoes because I am jumping or rolling on the ground. I apply these advices of that teacher in my classes". Teacher 1 shows similarity between the way she was thought and she behaves to her students. "I saw that warm-up working in the practicum class and I got the attention of the students. I saw it was working so I apply them now due to the fact that it worked in my practicum". "Our high school English teacher used to meet us outside the class and send us messages in English. I liked that so much. Now, I have a whatsapp group and sometimes send them messages like study your lesson or I am writing lyrics. What is more, I am meeting some of my $7^{\text {th }}$ grade students outside the class".

Teacher 2 clarifies that the atmosphere of practicum and the class presentations at the university is different because everything was superficial at the university and it was not so much teacher-focused. Teacher 2 also remembers some good images from lecturers at the university. "They made me acquire the skills of planning and thinking critically. When I enter the class, I do not start the activity immediately as other teachers. In the first place, I do brainstorming activity, chat in Turkish (because they have lower proficiency in English and 
speaking) about those topics like the technological developments. I implement many things in my class I learned in my pre-service education".

It can be said from the statements above that both novice and experienced teachers in this study carry the trace of their images as learners in one way or another. This is in line with the idea of Lortie (1975) that teachers are getting socialized much more by previous teachers and the internalization of the model teacher observed during the process of being a student. It seems that Teacher 3 might have affected by her practicum school teacher in terms of giving importance to dressing smart, and Teacher 4 honestly explains that his teaching is the reflection of Mary. Teacher 2 seems to be under the influence of her parents who are also teachers. Teacher 1 seems to have been affected from her mother, teachers at the secondary school and university. These are related to the predispositions' impact in teacher socialization (Lortie, 1975).

As Lortie (1975) suggests, these kinds of images have a crucial impact on the socialization process of teachers in pre-service program and work place. Also, Teacher 2's those behaviors correspond with the psychoanalytical model that is about the effect of some crucial adults in people's lives as mothers and fathers (Wright, 1959; Wright \& Tuska, 1967). 'Apprenticeship of observation' is also viewed in the teachers in this study. According to Lortie (1975), teachers do lots of observations during their time as students about their teachers. These observations can have effects on teachers and these effects can be both positive and negative but it must be underlined that every teacher reflects upon these experiences and shapes their identity as a teacher in terms of these factors (Zeichner \& Gore, 1990). What is more, it can be seen that their identities describe their teaching styles (Aoki, 2012).

\section{Lack of support from colleagues}

Teacher 1 had problems resulted from her colleagues and her coordinator. "I do not see any Turkish English teacher. I am friend with two native teachers. Why do I not see them? They are envious of me. If you are liked by the students and prepare activities, this is the reason you are envied. My classes' success increased with the activities and the class liked me. The native speakers have improved themselves via courses. Due to this, they know some technics. 
I improved myself with them. But, the others (Turkish English teachers) are already burnout with this discouragement like what is the necessity? They affected me negatively".

Regarding the colleagues, Teacher 2 also could not take support from them. "They are generally older than me and the youngest one is 5 or 6 year-teacher. They somehow have found the easy way of the work and they do not worry about the documents as much as I do. They do not care about the children in particular. They just go and exit the lessons. They seem like to have found the practical way. But, they helped me in handling with the documents due to the fact that I do not know how to fill in any document. However, I had some problems in joint examinations because they thought that I might let the students cheat in the exam due to fact that I am new. They did not give any examinations in my lesson. There were some warnings to me about being on guard duty and there were some trying to repress me. They also discouraged me to do extra activities for the students saying that the students are stupid and they are useless".

Teacher 4 had positive support from his group leader at the private college but this did not happen in the state schools. "Our group leader was very helpful towards me maybe because the group leader was a foreigner. But, when I get to state school, I was the only English teacher and did not see any support from the director, because the director did not know anything. Nevertheless, I was lucky because I experienced many things at that private college. If I had started at that state school, I might have some trouble".

Teacher 3 also mentions "in my first school, I was alone and there was no colleague guiding me. No competition. It was an advantage for me, and I designed my own path. In my second school, I had foreign language class and I felt anxious in the first place because I had to study. There were some older colleagues in that school. It was hard in the first place to be a member of the school but they could not harm me a lot due to my self-confidence. There was this partner cooperation at those times. For example, my partner sent a message to me about teaching grammar. I got mad and wrote something to talk to her. But, fortunately, I let it go. I can tell that there is no effect of my colleagues, I guess I have a big ego".

It seems that all the teachers in this study had trouble with their colleagues in terms of support in the first years. It can be seen that Teacher 2 and Teacher 1 had great difficulty in adapting 
to the school environment due to lack of any supporting environment for the novice teacher, actually the responsibility of the school (Farrell, 2003). The communication problems with the colleagues can be a demotivating factor for teachers (Aydin, 2012; Farrell, 2001). The behaviors of colleagues may have led to a dilemma in the teachers in this study (Carew \& Lightfoot, 1979) because how the teachers in this study want to behave and what the reality is very different. Veenman (1984) defines this as reality shock shock and this causes "intense concerns about self survival" (Pigge \& Marso, 1987, p. 114). Thus, one of their main concerns seems to be survival (Akbulut, 2007). Also, it can be said that the universities may not be much successful at preparing pre-service teachers for real life in terms of pedagogical knowledge (Goodlad, 1990; Sykes, Bird, \& Kennedy, 2010). As Akbulut (2007) indicates though English teachers in his study claim to be communicative, they could not actualize their ideas to a great extent due to possibly limitations of the educational institution or course overload of the teachers. Akcan (2016) also mentioned the problems related to the implementation of communicative approach in the classes due to the fact that the classes are rather crowded and the teachers are supposed to prepare their learners for national examinations.

\section{Positive support from the authority}

Teacher 3 talks about the positive support of her director in her first school. "He used to support me a lot. He gave me a private room. He made me feel very valuable by saying that you graduated from a good university and you are the only English teacher of this school". With a regard to directors of the school, Teacher 2 had support from the director. "Thank God, my director is very nice. He supports whatever I do. Whenever I have something to copy or I need a source, he immediately takes actions". It can be assumed that personal liking between the teachers and the authority has a crucial process in socialization (Edgar \& Warren, 1969). However, Teacher 1 could not see any support from her coordinator due to the fact that the coordinator is not an English teacher. "The coordinator did not graduate from English Language Department. He reads lots of books related to language teaching but the books are theoretical. The book says there is this kind of way but does not always say that we have to apply each of them. But, what does this guy think? It will be done. He supposes that everything will work out as the book says. However, as teachers, we have to design our own philosophy”. As Teacher 4 explained previously he could not see any support from the 
director. He believes that he went through that process somehow easily thanks to his college experience.

It can be said that being a novice teacher and support from the director was a lucky condition for Teacher 2. Teacher 3 seems to have gone through those negative attitudes thanks to her personality (it will be discussed below widely). Teacher 1 seems to have bad times due to not being on the same page with her coordinator. It can be seen that personal liking between the teachers and the authority has a crucial process in socialization (Edgar \& Warren, 1969).

\section{Trial and error}

Teacher 2 explains "when I first entered the classroom, I had really hard times. I did not know what to do and I went to school without any preparation most of the time. How does the psychology of the class change when I go without any preparation? I observed all of them while I am experiencing them. You cannot leave the students alone. At one time, they broke the window, at another time they had a fight with each other. I thought many times to quit, the cultural environment is not pleasant and the student profile is bad. I am in the suburbs".

Teacher 1 had trouble when she got started to work due to the school's being new. "The institution I am working for is new. It has its own problems like the planning, curriculum. So, everyone has his/her own way. At least, they are experienced teachers. They can copy the program of the last year. But, I am new. I do not know how much time to allocate for past tense or for the introduction. I have guidance problem at the school in the first semester. In the second semester, I got more relaxed but in the first semester, I did not know whether I am ahead or behind the schedule. Does the student understand me?".

Looking at the Teacher 2's and Teacher 1's experiences, it can be said that they had to learn everything by trial and error (Deal \& Chatman, 1989) and by doing (Lortie, 1975). What is more, they seem to have focused on adapting to the policies, procedures and the system, which is what expected from the novice teachers in the first years (Deal \& Chatman, 1989). 


\section{Personality \& Commitment}

Teacher 3 implies that there was no one she inspired from while she is teaching and admits that she did not want to be a teacher in the first place. "I did not get to this department considering being a teacher. I got married at the university and I was working at a private company. I was getting too tired and due to this, my husband told me to get to the profession of teacher. That is how I started. But, I have this ideal in the life: whatever I do, I have to do the best. As a character, I get adapted quite quickly to the conditions. They were saying at those times 'I do not look like a beginning teacher'. I also did not grow up in the same place and with the same people. While I was 9-month baby, I was taken to Germany with my grandmother and aunt. Then, I came back at 11 ".

Teacher 4 is a very self-confident person as Teacher 3 and this has affected his teaching and his socialization process. "My background is as good as gold. Maybe, I am not a perfect English teacher, or I cannot teach so many things but I trust in myself a lot. I do not get scared of making mistakes. It is kind of self-confidence issue. I am very flexible about those matters".

Teacher 3 states that she did not have any difficulty in adapting to the schools or institutions due to her personality. "I did not have any difficulty in adapting to the schools, I never do actually. I ask for designation so easily".

It can be said that Teacher 3 and Teacher 4 seem to be aware of the reason of their existence and mission in a particular context, which is the inner and important part of the onion model suggested by Korthagen (2004) and Teacher 3 also attributes her success in being a teacher to her personality. "I am kind but firm. I can chat with anybody but I am very much aware of my duties and responsibilities. I can handle anything and I attribute this to my growing-up alone". It is in line with the notion that "teaching is an expression of who teachers are as people" (Cole \& Knowles, 2000, p. 2). It can be seen that Teacher 3 and Teacher 4 have shown commitment to teaching as a career (Anderson, 1974; Lacey, 2012) and this seems to be crucial in terms of feeling a member of the teacher community, namely, teacher socialization. What is more, we can see the effect of critical approach to teacher socialization here because Teacher 3 and Teacher 4 both have their own individualistic characteristics and try to adapt to 
the schools in order to become a member of the school (Zeichner \& Gore, 1990). Another reflection of this critical approach can be observed in terms of gender issues in Teacher 3's case. "Many women carry out teacher profession when they have time after they are done with housework. Most of the teachers do not exist alone but with their partners".

\section{Establishing rapport with the students}

Another point Teacher 3 emphasizes is that the teacher needs to get familiar with students' interests. "English teachers are always those keeping up with the era. I know each song the student listens to and I use them in my examples. They get surprised and think that the teacher also listens to same songs with us. You need to make sure to have good relationship, let them know that you understand them. Then, the student listens to you and learns".

Teacher 1 also believes in the importance of building familiarity with the students' needs. "I give three choices for the listening parts from the singers they listen to. They got surprised that I know those singers".

\section{The role of the pupils}

Teacher 2 states that her students had some negative effect on her development as a teacher and she really wanted to quit. "This place is not giving so much importance to education. The students are rather indifferent to the lesson. They do not listen to me most of the time and they are discouraging me a lot. If I had been in a good school, it would have been different. They consumed my teaching enthusiasm. I especially wanted to have a foreign language class but they even do not have interest in English. Most of them are in foreign class to avoid Math. What I carried out did not come to any conclusion". Teacher 2 also adds "they were used to classic methods. For example, there were no speakers in the school, and I brought speakers and a laptop from home. They got excited on the first day but on the second day, they got bored and started saying to go back to book and notebooks. This resulted in my burnout. I switched to classic method". This shows us the effect of functionalist approach to socialization (Burrell \& Morgan, 1979) in that Teacher 2 had to go back to the old, traditional way in order to provide consensus. Additionally, the findings ally with Aydin (2012)'s research in that an EFL teacher faced problems related to student demotivation to take part in 
her lessons and the parents' stance towards English learning. Akcan (2016) reported similar results in relation to the learners who are not motivated to learn.

Teacher 1 took positive feedback from the students and this made her feel good. "I have brought them extra materials. When I get positive feedback from the students, I felt job satisfaction. Due to the fact that there were some problems in the school, I committed myself to the students to avoid and forget the problems. If I had not liked the students or they behaved me gauchely or had not taken any feedback from them, I would probably have given it up".

Teacher 3 also clarifies that the children have positive effect on her teacher socialization. "The students in my first school were very low proficient. They were attractive for me because I both needed to train and educate them. This occupation keeps you always dynamic. When I see I have positive impact on the students' lives, I get happier. The more I get positive feedback from the students, the more I get committed to the profession".

Teacher 4 did not want to be an English teacher in the first place, but as time passed, Teacher 4 saw that he could endear himself to the students. "I did not start this profession like I was dying for teaching. I thought I already knew English and it was piece of cake for me. I liked the profession because I saw that the students liked me and I endeared myself".

These statements above are parallel with the notion that the teachers generally evaluate themselves with the positive feedback coming from the students (Shulman, 2013). What is more, this matches with Friebus' (1977) perspective that the role of the pupils is crucial in teacher socialization.

\section{Importance of being an English teacher}

Teacher 4 also believes that English teachers have a special place in the schools. "Other teachers see English teachers with different eyes, let's say, kind of envy. In this current school, we did not have a group room for English. I designed it and the director did anything I asked for. I order some extra book for the students and the director lets this". 
Teacher 3 also makes some explanations about being an English teacher. "There is no option for English teachers to be passive. I remember my English teacher dressing in a smart way. All English teachers are beautiful or at least they dress nicely. Of course, the beauty is subjective but when you enter the class, you have to get the attention of the students. She was like that and I noticed it. I see the importance of dressing in that teacher. I also give very much importance to this because firstly, you have to get the attention of the student. Then, with your intellectual knowledge, personality, and memes impress the students. After they have accepted you, they accept what you want to give".

It can be said that Teacher 3 and Teacher 4 believe in the importance of forming a professional identity, which is the expected result of the final phase in the socialization process (Jones, 1983). This is about both becoming aware of self and feeling the need to belong to a society (Kozulin, 2003).

2. What kinds of differences occur between novice and experienced teachers in terms of stories related to their socialization process?

It can be said that the experienced teachers in this study tend to refer to their personality in their socialization process. Teacher 3 confesses that "I have this ideal in the life: whatever I do, I have to do the best. As a character, I get adapted quite quickly to the conditions". Teacher 3 adds "there were some older colleagues in that school. It was hard in the first place to be a member of the school but they could not harm me a lot due to my self-confidence. There was this partner cooperation at those times. For example, my partner sent a message to me about teaching grammar. I got mad and wrote something to talk to her. But, fortunately, I let it go. I can tell that there is no effect of my colleagues, I guess I have a big ego". Teacher 4 also explains "My background is as good as gold. Maybe, I am not a perfect English teacher, or I cannot teach so many things but I trust in myself a lot. I do not get scared of making mistakes. It is kind of self-confidence issue. I am very flexible about those matters". They seem to be flexible and confident. It can be seen that they focus on their experiences they had gained throughout years (Jones, 1983). They try to endear themselves to the students because they believe this is a very important step in teaching English. 
It can be observed that the novice teachers in this study seem to focus on the problems more, which show similarity with the ones encountered in the studies of Akbulut (2007), Akcan (2006), Aydin (2012), and Farrell (1999). They seem to try to find a way to survive and to find solutions to these problems. Teacher 2 admits "when I first entered the classroom, I had really hard times. I did not know what to do and I went to school without any preparation most of the time. How does the psychology of the class change when I go without any preparation? I observed all of them while I am experiencing them". Teacher 1 expresses that "the coordinator did not graduate from English Language Department. He reads lots of books related to language teaching but the books are theoretical. The book says there is this kind of way but does not always say that we have to apply each of them. But, what does this guy think?". This can be called as adaptation process, which is about getting used to the procedures (Jones, 1983). It seems that the novice teachers in this study had really trouble in adapting to the school and really had hard times, which is the expected outcome in the first year (Johnson, 1996; Veenman, 1984). There must be cooperation between the teacher education programs and schools as suggested by Skerrett (2010). This is a kind of 'sink-orswim realities' (Varah, Theune, \& Parker, 1986) experienced by many beginning teachers during their first year. This is also in line with the stages described by Lortie (1975). In the first stage, the novice teacher tries to cope with day-to day struggles, which matches what the novice teachers tried to do. They also show great sign of apprenticeship of observation (Lortie, 1975).

\section{Conclusion}

This study investigated whether there is a relationship between the stories of teachers as learners in their socialization process and what kind of differences emerge between novice and experienced teachers in terms of their referring to that process from their perspective. It can be said that although there seems to be some similarity in terms of apprenticeship of observation between experienced and novice teachers in this study, the novice teachers in this study seem to refer to their stories as learners more than the experienced teachers in this study. What is more, there seems to be some differences in the themes they mention during their socialization process. While the novice teachers seem to focus on problems like lack of support from the colleagues, the dilemma between teacher education programs and the real 
teaching situation, the experienced teachers in this study seem to talk about their personality and they tend to give statement in the tone of advices.

\section{Pedagogical Implications}

The findings provide an in-depth understanding into teacher socialization from the perspectives of the teachers via their stories as learners. There seem to be many alignments between the theories and the findings of this study. Therefore, there are some pedagogical implications for teacher education programs and schools not only for pre-service teachers but also teachers. Firstly, teacher educators need to build a bridge between themselves and cooperating teachers at the school in order to be able to close the gap between what is advised at universities and real-life challenges, which may be about arranging sessions with school teachers about the problems they encounter in their own classes. Secondly, teacher educators need to provide their pre-service teachers with appropriate teacher educator models during their $4^{\text {th }}$ year program because pre-service teachers seem to copy them especially during the first years. Thirdly, the novice teachers need to work in cooperation with experienced teachers when they are assigned to their new schools because it seems that they have trouble in their classes, with their colleagues and institutional work. Due to the fact that the experienced teachers already seem to behave paternalistically as indicated by the findings, the synergy between novice and experienced teachers must be provided by the school administration by establishing rapport and providing reflection sessions related to such issues as teaching practices, classroom management etc. 


\section{References}

Akbulut, Y. (2007). Exploration of the beliefs of novice language teachers at the first year of their teaching endeavours. Selçuk University Journal of Social Sciences Institute, 17(1), $1-14$.

Akcan, S. (2016). Novice non-native English teachers' reflections on their teacher education programmes and their first years of teaching. PROFILE Issues in Teachers' Professional Development, 18(1), 55-70. http://dx.doi.org/10.15446/ profile.v18n1.48608.

Anderson, D. S. (1974). The development of student teachers: A comparative study of professional socialization. Paris: Organization for Economic Cooperation and Development.

Arfwedson, G. (1979). Teachers' work. In U. Lundgren, \& S. Patterson (Eds.), Code, context and curriculum processes (pp. 87-100). Stockholm, Sweden: Gleerup.

Aoki, N. (2012). The role of stories in teacher development. Perspectives on Individual Characteristics and Foreign Language Education, 6, 36-44.

Aydin, S. (2012). Factors causing demotivation in EFL teaching process: A case study. The Qualitative Report, 17(51), 1.

Barkhuizen, G., Benson, P., \& Chik, A. (2014). Narrative inquiry in language teaching and learning research. New York, NY: Routledge.

Bliss, L. B., \& Reck, U. M. (1991). PROFILE: An Instrument for Gathering Data in Teacher Socialization Studies. Retrieved from ERIC Document Reproduction Service No. 330 662.

Burrell, G., \& Morgan, G. (1979). Sociological paradigms and organizational analysis. London: Heinemann.

Bruckerhoff, C. E., \& Carlson, J. L. (1995). Loneliness, fear and disrepute: The haphazard socialization of a student teacher. Journal of Curriculum Studies, 24, 431-444.

Calderhead, J. (1992). Induction: a research perspective on the professional growth of the newly qualified teacher. In J. Calderhead, \& J. Lambert, (Eds.), The induction of newly appointed teachers (pp. 5-12). London: General Teaching Council. 
Carew, J., \& Lightfoot, S. L. (1979). Beyond bias: Perspectives on classrooms. Cambridge, MA: Harvard University.

Cole, A. L., \& Knowles, J. G. (2000). Researching teaching: Exploring teacher development through reflexive inquiry. Needham Heights, MA: Allyn \& Bacon.

Conle, C. (2000) Narrative Inquiry: Research tool and medium for professional development. European Journal of Teacher Education, 23(1), 49-63.

Crow, N. A. (1987). Socialization within a teacher education program: A case study (Yayımlanmamış doktora tezi). University of Utah, USA.

Darling-Hammond, L., \& Bransford, J. (Eds). (2005). Preparing teachers for a changing world: what teachers should learn and be able to do. San Francisco, CA: Jossey-Bass.

Deal, T. E. \& Chatman, R. M. (1989). Learning the ropes alone: Socializing new teachers. Action in Teacher Education, 11(1), 21-29.

Doyle, W. (1979). Classroom effects. Theory Into Practice, 18, 138-144.

Duff, P. A., \& Uchida, Y. (1997). The negotiation of teachers' sociocultural identities and practices in postsecondary EFL classrooms. TESOL Quarterly, 31(3), 451-486.

Duff, P. A., \& Bell, J. S. (2002). Narrative research in TESOL: Narrative inquiry: More than just telling stories. TESOL Quarterly, 36(2), 207-213.

Edgar, D. E., \& Warren, R. L. (1969). Power and autonomy in teacher socialization. Sociology of Education, 40, 316-333.

Farrell, T. S. (1999). The reflective assignment: Unlocking pre-service English teachers' beliefs on grammar teaching. RELC Journal, 30, 1-17.

Farrell, T. S. (2001). English language teacher socialization during the practicum. Prospect, $16,49-62$.

Farrell, T. S. (2003). Learning to teach English language during the first year: Personal influences and challenges. Teaching and Teacher Education, 19(1), 95-111.

Featherstone, H. (1993). Learning from the first years of classroom teaching: The journey in, the journey out. The Teachers College Record, 95(1), 93-112.

Feiman-Nemser, S. (1983). Learning to teach. In L. Shulman, \& G. Sykes (Eds.), Handbook of teaching and policy (pp. 150-170). New York, NY: Longman. 
Fraenkel, J. R., Wallen, N. E., \& Hyun, H. H. (2011). How to design and evaluate research in education. New York, NY: McGraw-Hill.

Friebus, R. J. (1977). Agents of socialization involved in student teaching. The Journal of Educational Research, 263-268.

Ginsberg, M., \& Clift, R. (1990). The hidden curriculum of pre-service teacher education. In r. W. Houston (Ed.), Handbook of research on teacher education (pp. 450-468). New York, NY: MacWilliams.

Given, L. M. (Ed.). (2008). The SAGE encyclopedia of qualitative research methods. Thousand Oaks, CA: Sage.

Goodlad, J. I. (1990). Places where teachers are taught. San Francisco, CA: Jossey Bass.

Haller, E. J. (1967). Pupil influence in teacher socialization: a socio-linguistic study. Sociology of Education, 316-333.

Hammerness, K. (2006). From coherence in theory to coherence in practice. The Teachers College Record, 108(7), 1241-1265.

Johnson, K. E. (1996). The vision versus the reality: the tensions of the TESOL practicum. In D. Freeman, \& J. Richards (Eds.), Teacher learning in language teaching (pp. 30-49). New York, NY: Cambridge University.

Johnson, K. E. (2009). Second language teacher education: A sociocultural perspective. New York, NY: Routledge.

Jones, G. R. (1983). Psychological orientation and the process of organizational socialization: An interactionist perspective. Academy of Management Review, 8(3), 464-474.

Korthagen, F. A., Kessels, J., Koster, B., Lagerwerf, B., \& Wubbels, T. (2001). Linking practice and theory: The pedagogy of realistic teacher education. Mahwah, NJ: Lawrence Erlbaum Associates.

Korthagen, F. A. J. (2004). In search of the essence o f a good teacher: towards a more holistic approach in teacher education. Teaching and Teacher Education, 20(1), 77-97.

Kozulin, A. (Ed.). (2003). Vygotsky's educational theory in cultural context. Cambridge, UK: Cambridge University.

Lacey, C. (2012). The socialization of teachers. Abingdon, Oxford: Routledge. 
Lortie, D. (1975). Schoolteacher: A sociological study. Chicago, IL: University of Chicago.

Pigge, F. L., \& Marso, R. N. (1987). Relationships between student characteristics and changes in attitudes, concerns, anxieties, and confidence about teaching during teacher preparation. The Journal of Educational Research, 81(2), 109-115.

Pollard, A. (1982). A model of classroom coping strategies. British Journal of Sociology of Education, 3, 19-37.

Power, P. G. (1981). Aspects of the transition from education student to beginning teacher. Australian Journal of Education, 25(3), 288-296.

Schön, D. A. (1983). The reflective practitioner: how professionals think in action. USA: Basic Books.

Shin, S. K. (2012). "It Cannot Be Done Alone": The socialization of novice English teachers in South Korea. TESOL Quarterly, 46(3), 542-567.

Shulman, L. S. (2013). Those who understand: Knowledge growth in teaching. In A. S. Mayes, \& B. Moon, Teaching and learning in the secondary school (pp. 125-137). USA: Routledge.

Skerrett, A. (2010). The interplay between teachers' biography and work context: effects on teacher socialization. Scholar-Practitioner Quarterly, 4(1), 79-93.

Solmon, M. A., Worthy, T., \& Carter, J. A. (1993). The interaction of school context and role identity of first-year teachers. Journal of Teaching in Physical, 12, 313-328.

Staton, A. Q., \& Hunt, S. L. (1992). Teacher socialization: Review and conceptualization. Communication Education, 41(2), 109-137.

Stephens, J. (1967). The processes of schooling. New York, NY: Holt, Rinehart and Winston.

Sykes, G., Bird, T., \& Kennedy, M. (2010). Teacher education: Its problems and some prospects. Journal of Teacher Education, 61(5), 464-476.

Tarone, E., \& Allwright, D. (2005). Second language teacher learning and student second language learning: shaping the knowledge Base. In D. J. Tedick (Ed.), Second language teacher education (pp. 5-23). Mahwah, NJ: Lawrence Erlbaum.

Ure, C. L. (2010). Reforming teacher education through a professionally applied study of teaching. Journal of Education for Teaching, 36(4), 461-475. 
Uzum, B. (2013). Foreign language teacher socialization: A multiple case study of foreign language teachers in an American higher education institution. (Unpublished doctoral dissertation). Michigan State University, USA.

Varah, L. J., Theune, W. S., \& Parker, L. (1986). Beginning teachers: sink or swim? Journal of Teacher Education, 37(1), 30-33.

Veenman, S. (1984). Perceived problems of beginning teachers. Review of Educational Research, 54, 143-178.

Xu, S. \& Connelly, F. M. (2009). Narrative inquiry for teacher education and development: Focus on English as a foreign language in China. Teaching and Teacher Education, 25(2), 219-227.

Zeichner, K. M. \& Gore, J. M. (1990). Teacher socialization. In W. R. Houston (Ed.), Handbook of research on teacher education (pp. 329-348). New York, NY: Macmillan.

Wright, B. (1959). Identification and becoming a teacher. Elementary School Journal, 59, 361-374.

Wright, B., \& Tuska, S. (1967). The childhood romance theory of teacher development. School Review, 25, 123-154. 


\section{Genişletilmiş Öz}

Öğretmen sosyalleşmesi öğretmenlik mesleği sürecine adaptasyon olarak adlandırılıp her öğretmenin bu süreçte farklı deneyimler yaşadığı gözlenmektedir. Nasıl öğretmeyi öğrenmenin kolay bir süreç olmadığının çalışmalarda vurgulandığı gözlenmektedir (Bruckerhoff \& Carlson, 1995; Featherstone, 1993; Solmon, Worthy, \& Carter, 1993). Ayrica, ilk yıllar, önünde uzun yıllar olan yeni öğretmenler için çok önemlidir (Solmon et al., 1993). Bütün bunlar ışığında öğretmen sosyalleşmesinin dinamik ve karmaşık bir yapıya sahip olduğu söylenebilir (Zeichner \& Gore, 1990).

Öğretmen sosyalleşmesi alanında fonksiyonel, yorumlayıcı ve eleştirel olmak üzere 3 farklı gelenek olduğu söylenebilir (Zeichner \& Gore, 1990). İlk olarak, fonksiyonel yaklaşım toplumu bireye üstün görür ve sosyal kuralları korumak, değerleri aktarmak ve ortak bir kanaat oluşturmak için yoğun bir çaba sarf eder (Burrell \& Morgan, 1979). Fonksiyonel yaklaşımın aksine, yorumlayıcı yaklaşım bireyin toplum içindeki öznelliğine ve eşsiz deneyimine önem verir (Burrell \& Morgan, 1979). Son olarak, eleştirel yaklaşımda vurgulanan ise bireyler toplumun hem katılımcısı hem de gözlemcisidir. Bu yüzden, eleştirel yaklaşımın amacı, bireylerde, toplumda sorgulanmadan kabul edilen olguları eleştirme becerisine yönelik farkındalığını artırmaktır (Zeichner \& Gore, 1990).

Öğretmen sosyalleşmesi sürecinin etkilendiği öğeler formal öğretmen eğitimi öncesinin öğretmen sosyalleşmesine etkisi, öğretmen yetiştirme eğitiminin sosyalleştirme rolü ve işyerinde ve kültürde sosyalleşme olarak sıralanabilir. Birinci olarak formal öğretmen eğitimi öncesinin öğretmen sosyalleşmesine etkisi kapsamında, öğrencilerin deneyimleri, alışkanlıkları ve öğrenilmiş davranışları olduğu ve bu deneyim, alışkanlık ve davranışları herhangi bir öğrenme ortamına getirmelerinin kaçınılmaz olduğu söylenebilir. $\mathrm{Bu}$ deneyimlerin, alışkanlıkların ve öğrenilmiş davranışların da öğretmen sosyalleşmesi üzerinde bir etkisinin olduğu gözlenmektedir (Bliss \& Reck, 1991; Duff \& Uchida, 1997; Farrell, 1999; Uzum, 2013; Zeichner \& Gore, 1990). Lortie (1975) bu eğilimlerin öğretmen sosyalleşmesi üzerinde öğretmen yetiştirme programlarından ve işyerinden daha önemli bir etkiye sahip olduğunu belirtmiştir. İkinci olarak, öğretmen yetiştirme eğitiminin sosyalleştirme rolü bağlamında Zeichner ve Gore (1990) üç alanın etkisinden bahsetmiştir: a) formal eğitim dışında tamamlanan genel eğitim ve akademik özel dersler, b) eğitim kapsamında tamamlanan 
öğretmenlik becerisine yönelik dersler ve c) genellikle okullarda gerçekleştirilen staj deneyimleri. Bunun yanı sıra öğretmen yetiştirme programlarının kalitesi, türü, sosyal ve politik özelliklerine yönelik çok az çalışmanın olduğu gözlemlenmiştir (Zeichner \& Gore, 1990). Ayrıca, yapılan çalışmalar öğretmen yetiştirme programlarında teori ve pratik arasında bir uyuşmazlık olduğunu vurgulamıştır (Darling-Hammond \& Bransford 2005; Hammerness, 2006; Korthagen et al., 2001; Ure, 2010). Böylece, bu uyuşmazlıktan dolayı mesleğe yeni başlayan öğretmenlerin sıkıntı çekme ihtimalleri olduğu söylenebilir. Üçüncü olarak, işyerinde ve kültürde sosyalleşme başlığı adı altında, kültürel, kurumsal ve interaktif faktörlerin etkisinden bahsedilebilir (Pollard, 1982). Öğrencilerin rolü ve sınıf ortamı interaktif faktörler altında sıralanabilir. Öğrencilerin rolü bu süreçte önemli bulunmuştur ve Haller (1967)'ın çalışmasında ilkokul öğretmenlerinin basitleştirilmiş bir dil kullanma eğiliminde oldukları görülmüştür. Bu durum da öğrencilerin öğretmen sosyalleşmesinde güçlü bir etkiye sahip olduğuna işaret etmektedir (Doyle, 1979; Haller, 1967). Türkiye'de çalışma yapanlar arasında Akbulut (2007), Aydin (2012) ve Akcan (2016) gösterilebilir. Akbulut (2007) yeni işe başlayan İngilizce öğretmenleriyle yaptığı çalışmada öğretmenlerin fikirsel olarak iletişim dil öğretim modelini savunsalar da sınıf ortamlarında muhtemelen ders yükü ve yönetimsel kısıtlamalardan dolayı pratikte bu modeli pek uygulayamadıkları gözlemlenmiştir. Aydin (2012) yabancı dil olarak İngilizce öğrenilen ortamlarda öğretmen demotivasyonuna sebep olan faktörleri araştırmıştır. Araştırmanın sonucunda problemlerin öğretmenlik mesleğine, öğretim programına, çalışma koşullarına, öğrenci ve ailelerine, meslektaşlarına, yöneticilere ve fiziksel koşullarla bağlantılı olduğunu gözlemlenmiştir. Akcan (2016) işe yeni başlayan İngilizce öğretmenlerinin eğitim aldıkları programların etkililiğine ilişkin fikirlerini ve öğretmenliğin ilk yıllarında karşılaştıkları zorlukları araştırmıştır. Öğretmenler eğitim gördükleri programlarda pratikten çok teoriye vurgu yapıldığını belirterek karşılaştıkları zorlukların sınıf yönetimi, iletişim dil öğretim modelinin uygulanması, motive olmamış öğrenciler ve öğrenme güçlüğü çeken öğrenciler ile ilgili olduğunu söylemişlerdir.

$\mathrm{Bu}$ bağlamda, öğretmen sosyalleşmesinin uzun ve karmaşık bir süreç olduğu söylenebilir. Ayrıca, öğretmen sosyalleşmesinin de çocukluk döneminin ilk aşamasından öğretmen yetiştirme programlarına kadar bir sürü faktörden etkilendiği gözlemlenmiştir. Bu yüzden, öğretmenlerin öğrenciliklerine ilişkin hikâyelerin, öğretmen sosyalleşmesine 1 şık tutması adına önemli bir yere sahip olduğu söylenebilir. Bunlara ek olarak, Staton ve Hunt (1992) 
öğretmen sosyalleşmesi deneyimlerinin bireye özgü deneyimler olduğunu vurgulamıştır. Bu bağlamda, öğretmenlerin kendi perspektiflerinden öğrenciliklerine ilişkin hikâyelerini öğrenmenin öğretmen sosyalleşmesi gibi karışık bir sürece 1şık tutacağı düşünülmektedir. Bütün bunlar göz önüne alındığında, araştırmacının bilgisine göre, deneyimli ve yeni öğretmenler arasında öğretmenlerin kendi perspektiflerinden öğrenciliklerine ilişkin hikâyeleri ile öğretmen sosyalleşmesi arasında bir farklılık olup olmadığına ilişkin bir çalışma yapılmamıştır. $\mathrm{Bu}$ kapsamda bu çalışmanın amacı, öğretmenlerin kendi perspektiflerinden öğrenciliklerine ilişkin hikâyeleri ile öğretmen sosyalleşmesi arasında bir ilişki olup olmadığını ve bu süreci anlatırken deneyimli ve yeni öğretmenler arasında ne tür farklılıklar olduğu araştırmaktır. Bu çalışmada, Türkiye'den 2 tanesi deneyimli 2 tanesi de 1 yllık olmak üzere 4 tane İngilizce öğretmeni 2014-2015 bahar döneminde yer almıştır. Çalışma verileri yarı yapılandırılmış görüşme formu ile toplanmıştır. Sorular literatürde belirtilen üç kategoriye göre hazırlanmıştır. Formdaki soruların araştırmacılar tarafından anlaşılır olup olmadığını bulmak için uzman görüşü alınmış ve pilot uygulama yapılmıştır. Çalışmaya ilişkin analizler içerik analizi ve kodlama yoluyla yapılmıştır.

Bulgular öğretmen perspektifi açısından, öğretmen sosyalleşmesine, öğrenciliklerine ilişkin hikâyeler yoluyla, derinlemesine bir kavrama sağlamıştır. Teoriler ile bulgular arasında benzerlikler saptanmıştır. Çalışmanın sonucunda yeni öğretmenlerin kendi hikâyelerinden yansımalara ve karşılaştıkları problemlere odaklanırken deneyimli öğretmenlerin kişilik ve öz güvenlerini ön plana çıkararak babacan bir tavırla deneyimlerinden bahsettikleri yönünde bir eğilime sahip oldukları gözlenmiştir. Ayrıca, deneyimli öğretmenler ile yeni öğretmenler arasında öğretmen sosyalleşmesine ilişkin bahsettikleri konular açısından farklılıklara rastlanmıştır. Bulgular öğretmenlerin öğrenciliklerine ilişkin hikâyelerine ve derinlemesine analiz ihtiyacına önem verilmesi gerektiğini vurgulamaktadır.

$\mathrm{Bu}$ bulgular 1şı̆̆ında birkaç öneri sunulabilir. Birincisi, öğretmen eğitmenleri kendileri ile okuldaki staj öğretmenleri arasında bir köprü kurup üniversitelerde öğretilen ile gerçek hayattaki zorluklar arasındaki açığı kapatmaya çalışmalıdırlar. İkincisi, öğretmen eğitmenleri öğretmen adaylarına iyi bir rol model olmalılardır çünkü öğretmen adaylarının özellikle ilk yıllarda kendi öğretmenlerini taklit ettikleri bu çalışmada saptanmıştır. Üçüncüsü, yeni atanan öğretmenler hem sınıflarında yaşadıkları hem de meslektaş ve idare ile karşılaştıkları problemleri aşmak için deneyimli öğretmenler ile işbirliği içinde çalışmalıdırlar. Hali hazırda 
Esra Harmandaoğlu Baz

deneyimli öğretmenler babacan davranma eğiliminde olduğu için de bu sinerji okul yönetimi tarafindan sağlanmalıdır. 